\title{
Innovation and Development of Evaluation Tools of KKNI Based for Learning Subject of Process Evaluation and Chemical Learning Results
}

\author{
Makharany Dalimunthe ${ }^{1}$, Gulmah Sugiharti ${ }^{2}$, Feri Andi Syuhada ${ }^{3}$ \\ \{makharanydalimunthe@unimed.ac.id ${ }^{1}$,gulmahsugiharti@yahoo.com ${ }^{2}$ \} \\ Chemistry Education, State University of Medan, Medan, Indonesia ${ }^{1,2,3}$
}

\begin{abstract}
The enactment of the KKNI (Indonesian National Curriculum Qualification) in learning activities in Unimed is a challenge for lecturers and students, one of which is that a lecturer must be able to develop his professional and pedagogical competencies such as compiling a learning evaluation tool in the course he teaches. One of the courses that we are able to do almost every year is the subject of Evaluation and Assessment of the learning outcomes of chemistry. The research group of lecturers in the field of expertise (KDBK) aims to: (1) develop innovative Evaluation Tool based on Indonesian National Curriculum Qualifications (KKNI) on subject of Evaluation Process and Chemistry learning outcomes, (2) validate and revise the results of the Development Evaluation Tool, (3) Do simple trial of Evaluation Tool on result development on learning the subject Evaluation process and chemistry learning outcomes. Preliminary research results indicate that. The research method used is Research and Development (R \& D), namely research methods to produce certain products, and test the effectiveness of these products. Feasibility analysis of Learning evaluation tools are carried out with the aim to determine whether the KKNI Evaluation Tool developed is suitable for use in the course of Evaluation process and learning outcomes of chemistry. Feasibility analysis is calculated using a percentage formula. Preliminary research results indicate that of KKNI evaluation tools for routine assignments were declared to be very feasible to use with a percentage of $90 \%$, while the CJR evaluation tool was feasible to be used with a percentage of $80 \%$, meanwhile CBR is feasible with a percentage of $80 \%$, Mini Research with a percentage of $90 \%$ declared very feasible. Manipulation of Idea with a percentage of $80 \%$ declared feasible and Project Assignments are declared to be feasible with percentage of $80 \%$. Thus it was concluded that the Learning Tools on subject of Evaluation and PHB Chemistry that being developed could be used in next research.
\end{abstract}

Keywords: Innovation, Learning tools, KKNI, Evaluation

\section{Introduction}

The government regulation on 2012 no 8 concerning the Indonesian National Qualification Framework is a reference and guideline in developing the curriculum, especially at the university level. The curriculum standard that is arranged in a higher education institution is based on meeting the Learning Outcomes (CP) or Learning Outcome (LO) targets, which can be fulfilled through the content and learning process. (Unimed, 2013)1) 
The implementation of IQF in learning activities is a challenge for lecturers, for instance a lecturer must be able to develop professional and pedagogical competencies such as compiling a learning evaluation tool in the course he teaches. One of the subjects used the IQF is the chemistry learning evaluation and assessment (PHB) course.

The IQF implementation includes an Assessment Concept that demands 6 concepts of measured tasks and abilities, namely Assessment of Critical Book Review, Assessment of Critical Research Review, Mini Research Assessment, Project Assessment, Engineering Ideas and Routine Tasks. The six concepts of appraisal must be made and controlled by a lecturer who will teach the subject.

At the Chemistry Education Study Program there is no six standard assessment concepts for the Chemistry Evaluation and PHB subjects. For this reason, the research team plans to make a concept for evaluating the Chemistry Evaluation and PHB courses to be used in future learning.

Based on a brief description of the Evaluation and PHB Chemistry courses, the discussion of this course covers the concept of planning and implementing the learning process and learning outcomes in the field of chemistry studies, concepts and implementation of measurement, assessment and evaluation, types of measuring instruments in the process and results of teaching and learning, tests and non-test, determine instrument validity and reliability, analyze test items, process measurement results data to determine evaluation results, and make reports. From this brief description, it can be seen that the courses of Evaluation and PHB Chemistry contain basic concepts of evaluation and measurement that can be used to solve problems related to daily life and its application in learning. (Sugiharti, 2014)2)

Evaluation Tools based on KKNI and Subject of Evaluation and PHB chemistry. The KKNI (Indonesian National Qualification Framework) is a reference and guideline in developing the curriculum, especially in university education. The curriculum can be interpreted as a document or written plan regarding the quality of education that students must possess through a learning experience. This understanding means that the curriculum must contain in one or several written documents or plans. Likewise, in determining the concept of valuation in a course, certain signs are needed to be able to achieve the expected goals. There are several concepts and abilities that are measured in an IQF-based curriculum, which can be achieved through assignments. Furthermore, Medan State University established 6 types of tasks to achieve the concepts and abilities that will be measured in a course, namely: Routine Tasks (TR); Critical Book Report (CBR); Critical Journal Report (CJR); Mini Research (MR); Project Tasks (TR); and Engineering Ideas (RI)

Process Evaluation and Chemistry Learning Outcomes courses are subjects at KDBK Education which discuss about; topics of the concept of planning and implementing the learning process and learning outcomes of chemistry, concepts and implementation of measurement, assessment and evaluation, types of measuring instruments in the process and results of teaching and learning; test and non-test, determine instrument validity and reliability, analysis of test and non-test items, process measurement results data to determine evaluation results, and make a report.

From the concepts listed in this course, it can be seen that the Chemistry Learning Evaluation course contains basic concepts of evaluation and measurement that can be used to solve problems related to everyday life. This course is a subject that is indispensable for a teacher or prospective teacher (education student) in preparing themselves as a teacher to be able to conduct assessments in the class as they should. 


\section{Research methodology}

Research and Development (R \& D) methods are research methods used to produce certain products, and test the effectiveness of these products. To be able to produce certain products, research is used in the form of needs analysis (used survey or qualitative methods) and to test the effectiveness of these products in order to function in the wider community, research is needed to test the effectiveness of these products. (Borg. W.R, 1983) 3)

This research was conducted in the Department of Chemistry Unimed which was held in 2018 , for students who took the course as much as 2 classes taken purposively.

The approach used in this research is a qualitative approach, namely the approach used to examine the condition of natural objects (Arikunto, 2011)4). Meanwhile the variety of research being used is descriptive to systematically describe the facts and characteristics of the subject precisely.

Data collection techniques in this study were carried out with instrument and questionnaire feasibility sheets. Feasibility analysis of Learning Evaluation tools are conducted with the aim to find out whether the Evaluation Tool developed is suitable to be used as an Evaluation Tool in the Evaluation and PHB chemistry courses. Feasibility analysis (Sugiyono, 2015) is calculated using the following formula:

$$
\begin{gathered}
\text { Percentage }=\text { Total score acquisition } \\
\text { Total score maximum }
\end{gathered}
$$

The percentage results obtained from the calculation are then seen as the assessment criteria as in Table 1.

Table 1. Assessment of Feasibility of Evaluation Tools

\begin{tabular}{lll}
\cline { 2 - 3 } No & Value \% & Assessment Category \\
\cline { 2 - 3 } 2 & $0-20$ & Very unworthy \\
2 & $21-40$ & Unworthy \\
3 & $41-60$ & Quite \\
4 & $61-80$ & Feasible \\
5 & $81-100$ & Very Feasible
\end{tabular}

(Source: Sugiyono, 2015) ${ }^{5}$ )

The response results (student questionnaire) also calculated the percentage using the percentage formula above. To score the questionnaire on the average value of the frequency 
distribution results calculated based on the alternative answers the sample can be seen in Table 2.

Table 2. Assessment score questionnaire

\begin{tabular}{|c|c|c|}
\hline No & Value \% & Assessment category \\
\hline 1 & $80-100$ & Very good \\
\hline 2 & $66-79$ & $\begin{array}{l}\text { Go } \\
n \text { d }\end{array}$ \\
\hline 3 & $56-65$ & $\underset{\text { ito }}{\mathrm{Qu}}$ \\
\hline 4 & $46-65$ & $\begin{array}{l}\text { B } \\
a d\end{array}$ \\
\hline 5 & $0-45$ & $\begin{array}{l}F \\
-: 1\end{array}$ \\
\hline
\end{tabular}

(Source: Silitonga, 2014) 6

\section{Result and discussion}

The results obtained during the initial research are the making the instrument of 6 KKNI assignments in the Chemistry Evaluation and PHB courses in the form of 6 standardized tasks. Before the field trial was conducted, the KKNI-based evaluation tools were first reviewed by 2 validators who were experts in the Chemistry Evaluation and PHB subjects. Validation results show that the KKNI-based evaluation tools in the Chemistry Evaluation and PHB courses are as follows.

Based on the results of a review of the Student Routine Task Force (TR) in the Evaluation and Assessment of Chemistry Learning Outcomes subject, it can be concluded that the Routine Task Tool of students is very feasible, with a percentage of $90 \%$. Validator Suggest that the routine tasks given to students are made at a higher level of cognition, no longer in the form of $\mathrm{C} 1$ and C2. Thus the Routine Task Evaluation Tool based on the KKNI in the Chemistry Learning Outcomes Evaluation and Assessment course can be used in the learning of Chemistry Evaluation and PHB courses.

The results of the review of the CJR (Critical Journal Report) Evaluation Tool found that the CJR evaluation tool was feasible to be used in the learning of evaluation and PHB Chemistry courses, with a percentage of $80 \%$. While the advice from reviewer /validator so that the criticized journals are scopus indexed journals.

The results of the review of the CBR (Critical Book Report) Evaluation Tool found that the CBR evaluation tool was feasible to be used in the learning of evaluation and PHB Chemistry courses, with a percentage of $80 \%$. While the advice from reviewer / validator is that it is better that the book reviewed be supplemented with other books, namely textbooks that smell evaluation. 
The results of a review of the Mini Research (MR) instrument found that the Mini Research evaluation tool was very feasible to use in the learning of Chemistry and PHB evaluation subjects, with a percentage of $90 \%$. While reviewer / validator states that it is even better if the questions used in mini-research instruments are not only in the form of multiple choice questions, but also inserted with questions in the form of test essays.

The results of the review of the Idea Engineering (RI) instrument found that the Idea Engineering evaluation tool was feasible to be used in the learning of evaluation and PHB Chemistry courses, with a percentage of $80 \%$. While the reviewer / validator suggested that the Idea Engineering format should be clarified with the addition of guidelines so that students would be easier to express their ideas.

The results of a review of the Project Task instrument found that the Project Task evaluation tool was very feasible to be used in the learning of evaluation and PHB Chemistry courses, with a percentage of $80 \%$. From the results of the preliminary research above, it was concluded that the Learning Evaluation and PHB Chemistry Learning Tools that had been developed could be used in subsequent studies.

\section{References}

[1] Unimed.: Tim Pengembang Kurikulum Unimed,.Buku Pedoman Pengembangan Kurikulum (2013)

[2] Sugiharti, G.:. Evaluasi dan Penilaian Hasil Belajar Kimia, FMIPA UNIMED Medan.ISBN 978- 602-7938-95-3. Pencatatan Hak Cipta 000110708 (2014)

[3] Borg, W.R dan Gall, M.D.: Educational Research: An Introduction. New York: Longman (1983)

[4] Arikunto,S.: Prosedur Penelitian Suatu Pendidikan Praktik, Rineka Cipta, Jakarta (2011)

[5] Sugiyono.:. Metode Penelitian Pendidikan (Pendekatan Kuantitatif, Kualitatif, dan R \& D).Alfabeta. Bandung. (2015)

[6] Silitonga. PM.:. Statistik Teori dan Aplikasi dalam Penelitian, FMIPA UNIMED. Medan (2014) 